\title{
Mealybug Vryburgia trionymoides (DeLotto) (Pseudococcidae) ${ }^{1}$
}

\author{
lan Stocks ${ }^{2}$
}

\section{Introduction}

On several occasions in 2011, succulents (Crassulaceae) for sale at retail stores in Florida were found with infestations of the mealybug Vryburgia trionymoides DeLotto. A traceback revealed that the succulents originated in California, where this mealybug is known as an occasional greenhouse pest. Vryburgia trionymoides was first detected in Florida in 2002 at several discount retailers in Volusia, Lake and Palm Beach counties, and was not detected again until 2005, again in Volusia County. After 2005, Vryburgia trionymoides was not seen again in Florida until 2011, when it was spotted in Nassau County.

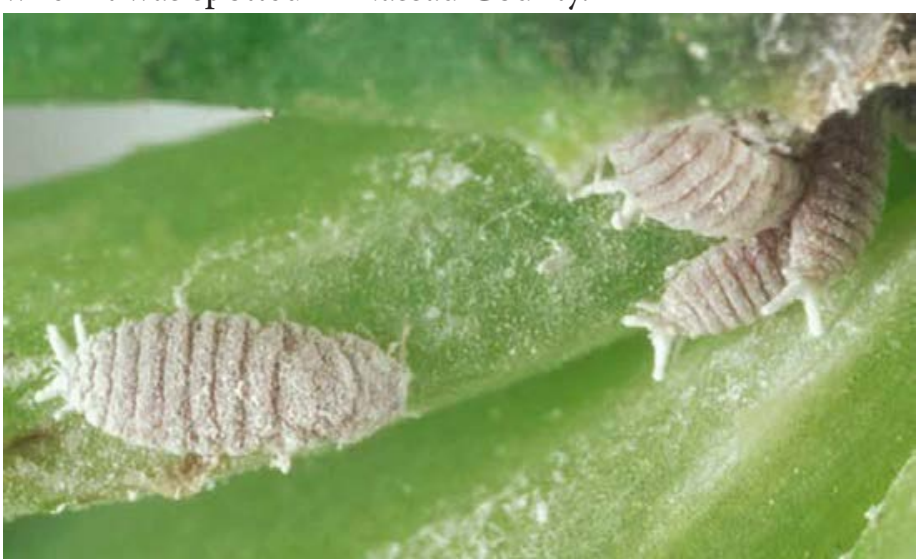

Figure 1. Adult females of Vryburgia trionymoides on a succulent leaf. Credits: Lyle Buss, University of Florida, Entomology and Nematology.

\section{Distribution}

Described originally from Kenya, this species is presumed to be native to Africa. Outside of Africa, it has been intercepted in South Korea (Soo Jung Suh, personal communication, National Plant Quarantine Service, Republic of Korea), once in the U.S. from Mexico (Greg Evans, personal communication, USDA-APHIS-PPQ), and is considered at least locally established in parts of southern California (Gillian Watson, personal communication).

\section{Description}

This mealybug is pinkish-purple, with a light coating of white wax over the body, and thick white filaments arising from the tip of the abdomen. The pinkish-purple body color may be obscured by the powdery wax coating. Other mealybug species likely to be encountered on Crassulaceae include Planococcus citri (Risso) (citrus mealybug), Phenacoccus solani Ferris (solanum mealybug) and several species of Pseudococcus. In general, identification requires slide-mounting to observe morphological characteristics.

\section{Biology}

Little is known about the biology of this species. It is most commonly collected on succulent plants in the family Crassulaceae. Occasionally, the similar species Vryburgia brevicruris (McKenzie), known from California, is found infesting succulents in Florida. Specimens intercepted or

1. This document is EENY553, originally published as DPI Entomology Circular 424, one of a series of the Entomology and Nematology Department, Florida Cooperative Extension Service, Institute of Food and Agricultural Sciences, University of Florida. Original publication date April 2013. Visit the EDIS website at http://edis.ifas.ufl.edu.

2. Ian Stocks, taxonomic entomologist, Florida Department of Agriculture and Consumer Services, Division of Plant Industry, and affiliate faculty, Entomology and Nematology Department, Institute of Food and Agricultural Sciences, University of Florida, Gainesville, FL 32611.

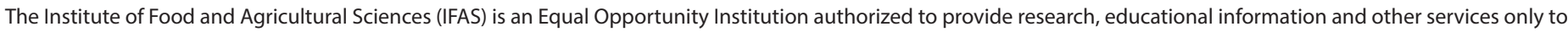

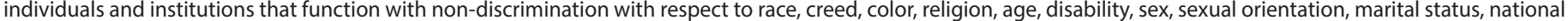
origin, political opinions or affiliations. U.S. Department of Agriculture, Cooperative Extension Service, University of Florida, IFAS, Florida A\&M University Cooperative Extension Program, and Boards of County Commissioners Cooperating. Nick T. Place, Dean 
found in retail stores often were well-hidden in the axillary region near the stem, making detection more challenging.

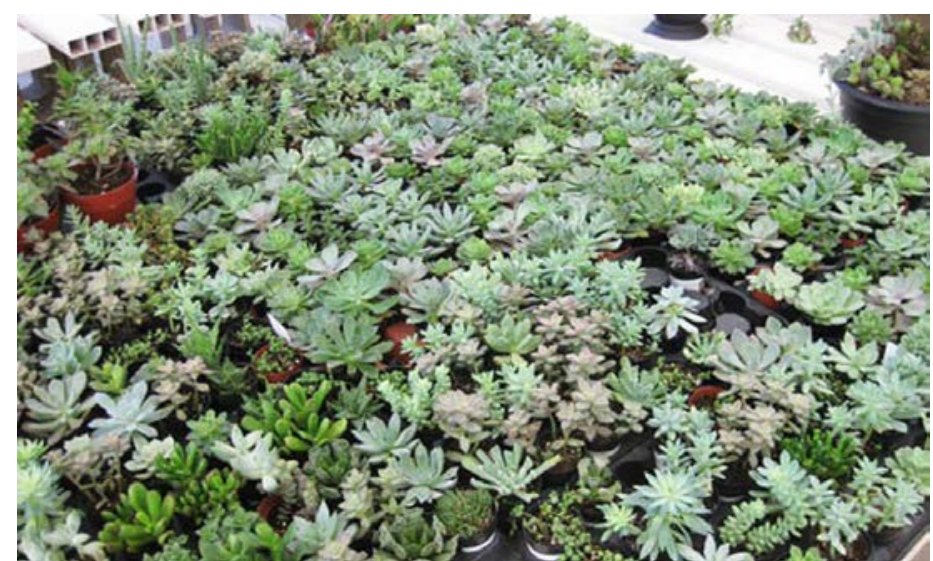

Figure 2. Succulents from California at a Florida distribution center ready for shipment to retailers.

Credits: Ian Stocks, Florida Department of Agriculture and Consumer Services, Division of Plant Industry.

\section{Hosts}

Asclepiadaceae - Caralluma dummeri (N. E. Br.) A.C. White and B. Sloane, Huernia sp.

Aizoaceae - Aeonium spp., Carpobrotus spp.; Lithops sp.

Crassulaceae - Aeonium spp., Crassula spp., Dudleya spp., Echeveria spp., Graptopetalum sp., x

Pachyveria, Sempervivum spp.

Asteraceae - Senecio sp.

Liliaceae - Aloe sp., x Amarcrinum (Gillian Watson, personal communication, CDFA)

\section{Economic Importance}

There are no published reports of economic losses caused by this species. Gillian Watson (personal communication, CDFA) reports that even though an untreated infestation can kill a plant, it has not had an economic effect on succulent production in California.

\section{Natural Enemies}

There is no published report of natural enemies. The Universal Chalcidoidea Database contains records for four species of parasitoids associated with an unidentified Vryburgia species, and one species (Anagyrus fusciventris Girault) for the related mealybug V. lounsburyi, which is also known from California. Anagyrus fusciventris is recorded from Florida, and a second species, identified only as Aphycus sp., is listed from Florida.

\section{Selected References}

Anonymous. 1994. California plant pest and disease report. California Department of Food and Agriculture. (10 September 2012.)

DeLotto G. 1961. New Pseudococcidae (Homoptera: Coccoidea) from Africa. Bulletin of the British Museum (Natural History) Entomology 10: 211-238.

Laflin H, Gullan PJ, Parrella MP. 2004. Mealybug species (Hemiptera: Pseudococcidae) found on ornamental crops in California nursery production. Proceedings of the Entomological Society of Washington 106: 475-477. 